\title{
Does severity of dermatochalasis in aging affect corneal biomechanical properties?
}

\author{
This article was published in the following Dove Press journal: \\ Clinical Interventions in Aging \\ 17 May 2016 \\ Number of times this article has been viewed
}

\author{
Kurșat Atalay \\ Ceren Gurez \\ Ahmet Kirgiz \\ Kubra Serefoglu Cabuk \\ Department of Ophthalmology, \\ Bagcilar Training and Research \\ Hospital, Istanbul, Turkey
}

Correspondence: Kurșat Atalay

Department of Ophthalmology, Bagcilar Training and Research Hospital, Bagcilar Merkez, 34200, Istanbul, Turkey

Tel +90 2124404000

Email drkursatalay@gmail.com
Purpose: The aim of this study was to investigate the possibility of a relationship between corneal biomechanical properties and different grades of dermatochalasis.

Patients and methods: Patients were assigned to four groups according to the severity of their dermatochalasis: normal (Group 1), mild (Group 2), moderate (Group 3), and severe (Group 4). An Ocular Response Analyzer device was used to measure corneal hysteresis $(\mathrm{CH})$, corneal resistance factor (CRF), and corneal-compensated intraocular pressure ( $\mathrm{IOP}_{\mathrm{cc}}$ ).

Results: We found no significant differences in the mean values of the $\mathrm{CH}, \mathrm{CRF}$, and IOP of all groups $\left(P=0.75, P=0.93\right.$, and $P=0.11$, respectively). However, $\mathrm{CH}$ and $\mathrm{IOP}_{\mathrm{cc}}$ were negatively correlated in Group 1, Group 2, and Group 3 patients $(P=0.013, r=-0.49 ; P=0.015, r=-0.52$; and $P=0.011, r=-0.47$, respectively), but this correlation was not apparent in the Group 4 patients $(P=0.57, r=0.12)$. $\mathrm{CRF}$ and $\mathrm{IOP}_{\mathrm{cc}}$ were correlated, but only in Group $4(P=0.001, r=0.66)$.

Conclusion: Severe dermatochalasis was associated with altered corneal biomechanical properties. Some of the important visual consequences of dermatochalasis and related diseases (such as floppy eyelid syndrome) can be understood by considering corneal biomechanical alterations.

Keywords: cornea, dermatochalasis, corneal hysteresis, corneal resistance factor, corneal biomechanical properties

\section{Introduction}

The eyelid and anterior segment of the eye are related both developmentally and functionally. ${ }^{1,2}$ Loosening of the skin around the eye, which is also called dermatochalasis, can be seen to occur genetically or is acquired with different associations such as aging and floppy eyelid syndrome (FES). ${ }^{3-6}$ Dermatochalasis causes differences in biomechanical properties of the skin, and histologic samples of the connective tissue show related alterations in the skin and the ocular surface of patients with this condition. ${ }^{7,8}$ However, a gap exists in the evaluation of biomechanical properties of the cornea - a major optical tissue of anterior segment - in dermatochalasis patients. In this study, we examined the corneal biomechanical alterations associated with dermatochalasis. We tried to investigate the possibility of a relationship between corneal biomechanical properties and different grades of dermatochalasis.

The skin of the eyelid and the ocular surface both contain large amounts of collagen and elastic fibers. The biomechanical alterations seen in the dermis and the cornea of dermatochalasis patients may therefore result from disruptions of these collagen and elastin fibers., ${ }^{4-11}$ The corneal biomechanical properties are also related to several connective tissue and eyelid diseases such as Marfan syndrome (MS) and FES. ${ }^{12,13}$

Corneal hysteresis $(\mathrm{CH})$ and corneal resistance factors (CRFs) are two important biomechanical properties that can be analyzed in vivo and are related to the viscous 
properties of the cornea. The viscoelastic mechanical damping ability of the cornea is described as $\mathrm{CH}$, while the CRFs determine the overall viscoelastic resistance of the cornea. Previous studies ${ }^{14-16}$ show a wide range of $\mathrm{CH}$ and $\mathrm{CRF}$ results in normal eyes and in eyes with different pathologies. However, to the best of our knowledge, this is the first report to evaluate the corneal biomechanical changes associated with dermatochalasis.

\section{Patients and methods}

\section{General information}

This prospective cross-sectional study was conducted at the Bagcilar Training and Research Hospital between July 2014 and July 2015. Bagcilar Training and Research Hospital ethics committee provided approval for the study. Patients were informed about the study protocol and written consent was obtained. The patients and the control group underwent best-corrected visual acuity (BCVA) measurement with a Snellen chart, evaluation with biomicroscopy, intraocular pressure (IOP) measurement with calibrated Goldmann applanation tonometry $\left(\mathrm{IOP}_{\mathrm{GAT}}\right)$, and mydriatic funduscopic examination. Patients with previous ocular surgery, pterygium, pinguecula, or corneal scarring, in addition to those who wore contact lenses, were excluded. Patients showing signs of keratoconus and glaucoma underwent additional tests, such as corneal topography, optic coherence topography, and visual field analysis. If the additional tests confirmed suspicions of keratoconus and glaucoma, these patients were also excluded. Refractive error was another exclusion criterion. Patients with myopia greater than -3.0 diopters and hyperopia greater than +3.0 diopters were also eliminated. The spherical equivalents of the refractive errors were used for analysis of refractive error in the patients.

\section{Patient selection}

Phenotypic classification of the patients was made according to the suggestions of Jacobs et al. ${ }^{17}$ Four groups were generated: normal (the upper eyelid skin does not touch the eyelashes, Group 1), mild (the upper eyelid skin just touches the eyelashes, Group 2), moderate (the upper eyelid skin hangs over the eyelashes, Group 3), and severe (the upper eyelid skin hangs over the eye, Group 4). Two ophthalmologists (AK, CG) evaluated the phenotypic findings of the patients. An expert opinion was obtained from an oculoplastic surgeon $(\mathrm{KC})$ when any debate arose regarding the classification of a patient.

\section{Instrumentation}

The central corneal thickness (CCT) was measured with an ultrasonographic pachymeter (AccuPach; Accutome Ultrasound Inc., Malvern, PA, USA). Three measurements were recorded by the same physician (AK) and the mean value was reported. All measurements were taken between 10 am and $4 \mathrm{pm}$ to minimize the diurnal effect. A drop of topical anesthetic (proparacaine $\mathrm{HCl}: 0.5 \%$ ) was instilled before the examination.

The biomechanical properties of the cornea were measured with the Ocular Response Analyzer ${ }^{\circledR}$ (ORA) (Reichert Ophthalmic Instruments, Buffalo, NY, USA). The measurement technique and characteristics of the ORA are described elsewhere. ${ }^{18,19}$ Briefly, the device uses a rapid air impulse for inward and outward applanation of the cornea. Because the cornea is a viscoelastic tissue, it dissipates some of the energy generated by the air impulses. Thus, the two applanation points occur at different levels. As corneal shape changes by inward and outward applanation, an electro-optical system monitors the complete process and calculates two independent IOP values, $P 1$ and $P 2$. The difference $P 1-P 2$ gives the $\mathrm{CH}$. A software program embedded in the hardware of the ORA calculates CRF using the following formula: $\mathrm{CRF}=P 1-k P 2$, where $k$ is a constant generated from the analysis of the relationship between CCT and $P 1 / P 2$. The device gives two IOP measurements: the first is $\mathrm{IOP}_{\mathrm{g}}$, which is equivalent to $\mathrm{IOP}_{\mathrm{GAT}}$; the second one is cornealcompensated intraocular pressure $\left(\mathrm{IOP}_{\mathrm{cc}}\right)$, which is obtained from the calculation of the specific linear combination of $P 1$ and $P 2 .{ }^{20}$ Thus, the IOP ${ }_{\text {cc }}$ obtained with ORA shows more accurate IOP results than Goldmann applanation tonometry. The ORA gives a wave score for assessing the quality of the measurement. At least three measurements were obtained in this study. The eye having the best wave score was included in the study. All measurements were done before mydriatic eyedrop instillation. The IOP $_{\mathrm{GAT}}$ and ORA measurements were performed by the same physician (KA).

\section{Statistical tests}

The Statistical Package for the Social Sciences software version 21.0 (IBM Corporation, Armonk, NY, USA) was used for statistical testing. All continuous variables were tested for normality. The chi-square test was used for comparison of categorical groups. Analysis of variance (ANOVA) was conducted to compare the mean values of continuous variables among groups. The Tukey's honest significant difference test was used for post hoc comparisons after ANOVA. The Pearson correlation analysis was used to test bivariate correlations among variables. All results are given as mean \pm standard deviation. A $P$-value $\leq 0.05$ was regarded as statistically significant.

\section{Results}

Ninety-five eyes of 95 patients were evaluated. The number of control patients (Group 1) was 25 . The numbers of mildly 
Table I Some descriptive values for the groups in this study

\begin{tabular}{|c|c|c|c|c|c|}
\hline Descriptive parameters & Group I & Group 2 & Group 3 & Group 4 & $P$-value* \\
\hline \multicolumn{6}{|l|}{ Sex } \\
\hline Male (n) & 4 & 6 & 4 & 8 & $P_{1}=0.23$ \\
\hline Female (n) & 21 & 15 & 23 & 14 & \\
\hline \multicolumn{6}{|l|}{ Age, years } \\
\hline Mean \pm SD & $48.7 \pm 13.8$ & $50.9 \pm 11.1$ & $54.2 \pm 10.7$ & $56.8 \pm 9.7$ & $P_{2}=0.084$ \\
\hline Range, minimum-maximum & $|8-8|$ & $28-72$ & $29-70$ & $39-83$ & \\
\hline \multicolumn{6}{|l|}{ Spherical equivalents, diopters } \\
\hline Mean \pm SD & $0.23 \pm 1.01$ & $0.3 \pm 0.89$ & $0.25 \pm 0.9$ & $0.36 \pm 1.06$ & $P_{3}=0.96$ \\
\hline Range, minimum/maximum & $-2.5 / 2.0$ & $-1.5 / 1.0$ & $-1.0 / 2.0$ & $-2.0 / 1.75$ & \\
\hline \multicolumn{6}{|l|}{ BCVA } \\
\hline Mean \pm SD & $0.96 \pm 0.12$ & $0.97 \pm 0.1$ & $0.97 \pm 0.09$ & $0.93 \pm 0.13$ & $P_{4}=0.25$ \\
\hline Range, minimum/maximum & $\mathrm{I} / \mathrm{I}$ & $\mathrm{I} / \mathrm{I}$ & $\mathrm{I} / \mathrm{I}$ & $\mathrm{I} / \mathrm{I}$ & \\
\hline \multicolumn{6}{|l|}{$\mathrm{CCT}, \mu \mathrm{m}$} \\
\hline Mean \pm SD & $556.2 \pm 38.6$ & $554.8 \pm 25.6$ & $532.0 \pm 37.0$ & $545.1 \pm 33.3$ & $P_{5}=0.052$ \\
\hline Range, minimum/maximum & $508 / 655$ & $517 / 618$ & $478 / 621$ & $483 / 599$ & \\
\hline
\end{tabular}

Notes: *The value of $P_{1}$ was obtained with the chi-square test. $P_{4}$ was gained with Kruskal-Wallis test. The $P_{2}-, P_{3}$-, and $P_{5}$-values were calculated using one-way ANOVA test. Abbreviations: BCVA, best-corrected visual acuity; CCT, central corneal thickness; ANOVA, analysis of variance.

(Group 2), moderately (Group 3), and severely (Group 4) affected patients were 21, 27, and 22, respectively. All data except the BCVA showed a normal distribution in all groups (Kolmogorov-Smirnov test for BCVA in all groups; $P=0.000)$. Some of the descriptive data are summarized in Table 1.

The $\mathrm{CH}$ and CRF showed no significant differences in all groups based on one-way ANOVA analysis $(P=0.75$ and $P=0.93$, respectively). The comparison of $\mathrm{IOP}_{\mathrm{GAT}}$ and $\mathrm{IOP}_{\mathrm{cc}}$ values in all groups also showed no significant differences with a one-way ANOVA test $(P=0.91$ and $P=0.11$, respectively). The mean values of $\mathrm{IOP}_{\mathrm{GAT}}, \mathrm{IOP}_{\mathrm{cc}}, \mathrm{CH}$, and $\mathrm{CRF}$ are shown in Table 2.

A matrix analysis was conducted for correlation analysis and some statistically significant correlations calculated with Pearson correlation analysis are shown in Table 3.

Our study showed a significant association between the severity of dermatochalasis and corneal biomechanical properties. First, we found a negative correlation between $\mathrm{CH}$ and IOP $_{\text {cc }}$ in Group 1, Group 2, and Group 3, but no correlation in Group 4. Second, CRF and IOP ${ }_{c c}$ were positively correlated, but only in Group 4. Third, $\mathrm{IOP}_{\mathrm{GAT}}$ and $\mathrm{IOP}_{\mathrm{cc}}$ were correlated, but again only in Group 4.

\section{Discussion}

The cornea, as a biomechanically measurable viscoelastic tissue, is composed of $90 \%$ connective tissue stroma. ${ }^{19,21}$ Different aspects of the cornea show different characteristics in normal and pathological conditions. For example, some studies ${ }^{22,23}$ have shown alterations in the corneal topographies of dermatochalasis patients. Other studies have revealed corneal biomechanical changes in diseases related to connective tissue and skin, such as MS and FES. ${ }^{12,13}$ We evaluated the biomechanical aspects of the cornea in dermatochalasis patients.

Several studies ${ }^{22,23}$ have been conducted on corneal topography in an attempt to explain the improved visual functions expressed by patients following surgical treatment of dermatochalasis. These studies mainly show clinically insignificant, but statistically relevant, corneal topographic alterations. Some reports ${ }^{24,25}$ also indicate improved contrast sensitivity, with alterations only in the high-order aberrations. The CCT, an important value for corneal structure, was unchanged in these studies. Our study also showed no statistical difference between all groups in terms of CCT, $\mathrm{CH}$, and CRF. However, we found a negative correlation between $\mathrm{CH}$ and $\mathrm{IOP}_{\mathrm{cc}}$ in Groups 1, 2, and 3, but no correlation in Group 4. The CRF was also not correlated with IOP in Groups 1, 2, and 3, but a positive association was present in Group 4. It has been known that the IOP level may affect the function of corneal endothelium, resulting in alterations in the measurement of CCT. ${ }^{26,27}$ However, no differences were noted in the CCT of all groups. Corneal shape is related to its biomechanical properties; therefore, an increased severity of dermatochalasis may contribute to the contrast sensitivity alterations observed in these patients.

Current literature contains limited data regarding the biomechanical associations of the genetically inherited form of dermatochalasis and corneal biomechanical properties. ${ }^{4}$ The genetically heritable diseases of connective tissues, such as MS, may affect the biomechanics of these tissues. Kara et $\mathrm{al}^{12}$ reported a difference in the $\mathrm{CH}$ and $\mathrm{CRF}$ of MS 
Table 2 The descriptive statistics of $\mathrm{IOP}_{\mathrm{GAT}}, \mathrm{IOP}_{\mathrm{cc}}, \mathrm{CH}$, and CRF

\begin{tabular}{|c|c|c|c|c|}
\hline & Minimum & Maximum & Mean & SD \\
\hline \multicolumn{5}{|l|}{ Group I (n=25) } \\
\hline $\mathrm{IOP}_{\mathrm{GAT}}, \mathrm{mmHg}$ & II & 20 & 16.24 & 2.29 \\
\hline $\mathrm{IOP}_{\mathrm{cc}}, \mathrm{mmHg}$ & 12.1 & 22.6 & 16.05 & 2.59 \\
\hline $\mathrm{CH}$ & 8.3 & 12.6 & 10.02 & 1.35 \\
\hline CRF & 7 & 12 & 9.98 & 1.45 \\
\hline \multicolumn{5}{|l|}{ Group $2(n=2 \mid)$} \\
\hline $\mathrm{IOP}_{\mathrm{GAT}}, \mathrm{mmHg}$ & II & 23 & 15.90 & 3.06 \\
\hline $\mathrm{IOP}_{\mathrm{cc}, \mathrm{mmHg}}$ & 11.3 & 26.8 & 18.16 & 3.62 \\
\hline $\mathrm{CH}$ & 6.9 & 13.9 & 9.67 & 1.59 \\
\hline CRF & 8 & 15 & 10.26 & 1.62 \\
\hline \multicolumn{5}{|l|}{ Group $3(n=27)$} \\
\hline $\mathrm{IOP}_{\mathrm{GAT}}, \mathrm{mmHg}$ & 10 & 21 & 15.70 & 2.47 \\
\hline $\mathrm{IOP}_{\mathrm{cc}} \mathrm{mmHg}$ & 11.4 & 22.7 & 17.04 & 2.98 \\
\hline $\mathrm{CH}$ & 7.5 & 13.2 & 9.80 & 1.34 \\
\hline CRF & 8 & 13 & 10.06 & 1.44 \\
\hline \multicolumn{5}{|l|}{ Group $4(n=22)$} \\
\hline $\mathrm{IOP}_{\mathrm{GAT}}, \mathrm{mmHg}$ & 12 & 22 & 15.91 & 2.95 \\
\hline $\mathrm{IOP}_{\mathrm{cc},} \mathrm{mmHg}$ & 13.4 & 22.5 & 17.42 & 2.66 \\
\hline $\mathrm{CH}$ & 7.4 & 11.2 & 9.65 & 1.01 \\
\hline CRF & 7 & 13 & 10.01 & 1.64 \\
\hline
\end{tabular}

Abbreviations: $I O P$, intraocular pressure; $1 \mathrm{OP}_{\mathrm{GAT}}, \mathrm{OP}$ measurement with calibrated Goldmann applanation tonometry; IOP $\mathrm{Cc}_{\text {, }}$ corneal-compensated IOP; $\mathrm{CH}$, corneal hysteresis; CRF, corneal resistance factor.

patients with ectopia lentis, which is a severe ophthalmic presentation of this disease. We did not find any differences in our groups of patients; we only found some alterations in the correlations between $\mathrm{CH}, \mathrm{CRF}$, and $\mathrm{IOP}_{\mathrm{cc}}$ in advanced dermatochalasis. This result may explain the more severe biomechanical findings seen in congenital connective tissue diseases such as MS, when compared to acquired diseases such as acquired dermatochalasis.

FES is another disease commonly seen with dermatochalasis. ${ }^{28} \mathrm{~A}$ recent report by Muniesa et $\mathrm{al}^{13}$ speculated that the patients with the most advanced FES may have major alterations in corneal biomechanics due to $\mathrm{CH}$. Adjustment of their patients for age and apnea-hypopnea index revealed a significant difference in the $\mathrm{CH}$ of FES patients.

An increase in matrix metalloproteinase activity is also a common finding in dermatochalasis, FES, and keratoconus. ${ }^{29-31}$ FES causes more extensive damage in the anterior segment of the eye, including the eyelid skin and the tarsus. ${ }^{3}$ Additionally, tarsal plate biomechanics plays an important role in the normal function of the eyelid and the anterior segment of the eye. ${ }^{32} \mathrm{~A}$ recent report by Kymionis et $\mathrm{al}^{33}$ described the failure of a corneal cross-linking treatment in a keratoconus patient with FES. Several studies ${ }^{28,34}$ have found some relationship between FES and keratoconus, which is also a degenerative disease of the cornea with distinct biomechanical alterations.
Table 3 The correlation analysis of all groups

\begin{tabular}{|c|c|c|c|c|c|}
\hline & Statistical results & IOP $_{\mathrm{GAT}}$ & IOP $_{c c}$ & $\mathrm{CH}$ & CRF \\
\hline \multicolumn{6}{|l|}{ Group I } \\
\hline \multirow[t]{2}{*}{$I O P_{G A T}$} & $r$ & 1 & 0.20 & 0.34 & 0.52 \\
\hline & $P$ & - & 0.33 & 0.09 & 0.007 \\
\hline \multirow[t]{2}{*}{$1 O P_{c c}$} & $r$ & 0.20 & I & -0.49 & 0.06 \\
\hline & $P$ & 0.33 & - & 0.013 & 0.76 \\
\hline \multirow[t]{2}{*}{$\mathrm{CH}$} & $r$ & 0.34 & -0.49 & I & 0.83 \\
\hline & $P$ & 0.09 & 0.013 & - & 0.00 \\
\hline \multirow[t]{2}{*}{ CRF } & $r$ & 0.52 & 0.06 & 0.83 & I \\
\hline & $P$ & 0.00 & 0.76 & 0.00 & - \\
\hline \multicolumn{6}{|l|}{ Group 2} \\
\hline \multirow[t]{2}{*}{$\mathrm{IOP}_{\mathrm{GAT}}$} & $r$ & I & 0.38 & 0.41 & 0.78 \\
\hline & $P$ & - & 0.08 & 0.05 & 0.00 \\
\hline \multirow[t]{2}{*}{$1 O P_{c c}$} & $r$ & 0.38 & I & -0.52 & 0.15 \\
\hline & $P$ & 0.08 & - & 0.015 & 0.50 \\
\hline \multirow[t]{2}{*}{$\mathrm{CH}$} & $r$ & 0.41 & -0.52 & I & 0.76 \\
\hline & $P$ & 0.056 & 0.015 & - & 0.00 \\
\hline \multirow[t]{2}{*}{ CRF } & $r$ & 0.78 & 0.15 & 0.76 & I \\
\hline & $P$ & 0.000 & 0.509 & 0.00 & - \\
\hline \multicolumn{6}{|l|}{ Group 3} \\
\hline \multirow[t]{2}{*}{$\mathrm{IOP}_{\mathrm{GAT}}$} & $r$ & I & 0.27 & 0.44 & 0.68 \\
\hline & $P$ & - & 0.17 & 0.02 & 0.00 \\
\hline \multirow[t]{2}{*}{$1 O P_{c c}$} & $r$ & 0.27 & I & -0.47 & 0.15 \\
\hline & $P$ & 0.17 & - & 0.011 & 0.42 \\
\hline \multirow[t]{2}{*}{$\mathrm{CH}$} & $r$ & 0.44 & -0.47 & I & 0.78 \\
\hline & $P$ & 0.02 & 0.011 & - & 0.00 \\
\hline \multirow[t]{2}{*}{ CRF } & $r$ & 0.68 & 0.15 & 0.78 & 1 \\
\hline & $P$ & 0.000 & 0.42 & 0.00 & - \\
\hline \multicolumn{6}{|l|}{ Group 4} \\
\hline \multirow[t]{2}{*}{$1 O P_{G A T}$} & $r$ & I & 0.7 I & 0.18 & 0.54 \\
\hline & $P$ & - & 0.00 & 0.41 & 0.008 \\
\hline \multirow[t]{2}{*}{$1 O P_{c c}$} & $r$ & I I & I & 0.12 & 0.66 \\
\hline & $P$ & 0.000 & - & 0.57 & 0.001 \\
\hline \multirow[t]{2}{*}{$\mathrm{CH}$} & $r$ & 0.18 & 0.12 & I & 0.82 \\
\hline & $P$ & 0.41 & 0.57 & - & 0.00 \\
\hline \multirow[t]{2}{*}{ CRF } & $r$ & 0.54 & 0.66 & 0.82 & 1 \\
\hline & $P$ & 0.008 & 0.001 & 0.00 & _- \\
\hline
\end{tabular}

Notes: Data in bold indicates statistical significance. "-" Indicates not applicable. Abbreviations: IOP, intraocular pressure; $\mathrm{IOP}_{\mathrm{GA}}, \mathrm{IOP}$ measurement with calibrated Goldmann applanation tonometry; IOP ${ }_{c c}$ corneal-compensated IOP; $\mathrm{CH}$, corneal hysteresis; CRF, corneal resistance factor.

One previous report indicated the importance of corneal stromal hydration in successful corneal cross-linking treatment. ${ }^{35}$ Moreover, epidermal dehydration leads to mechanobiological dysregulation, together with the decreased elasticity and viscoelasticity seen in dermatochalasis patients. ${ }^{6}$ According to our study, dermatochalasis may not be the only reason for $\mathrm{CH}$ alterations in FES patients; instead, the $\mathrm{CH}$ alterations may be due to extensive ophthalmic manifestations of FES. We evaluated only dermatochalasis patients without FES and found no differences in the $\mathrm{CH}$ and $\mathrm{CRF}$ of all groups. This finding may support the speculation of Muniesa et al. ${ }^{13}$

We should acknowledge some limitations of our study. First, we classified patients only according to their 
phenotypical appearance. The genotypical classification of patients may give a more extensive insight into the biomechanical findings of the cornea in dermatochalasis. Second, age is an important predisposing factor for dermatochalasis. A slight, gradual increment was present in the mean ages of the groups, but the difference was not statistically significant. Therefore, additional studies focusing on the age of dermatochalasis patients may improve the present findings.

\section{Conclusion}

Our study showed a positive correlation between CRF and $\mathrm{IOP}_{\mathrm{cc}}$ in severe dermatochalasis patients and a negative correlation between $\mathrm{CH}$ and $\mathrm{IOP}_{\mathrm{cc}}$ in normal people and patients with mild-to-moderate degrees of dermatochalasis. This study may explain why some of the dermatochalasis patients declare improved visual quality after blepharoplasty. Additionally, corneal biomechanical properties appeared not to be affected by dermatochalasis, as we found no significant differences in $\mathrm{CH}$ and $\mathrm{CRF}$ in all groups of patients.

\section{Disclosure}

The authors report no conflicts of interest in this work.

\section{References}

1. Arends G, Schramm U. The structure of the human semilunar plica at different stages of its development - a morphological and morphometric study. Ann Anat. 2004;186(3):195-207.

2. Zhang H, Hara M, Seki K, Fukuda K, Nishida T. Eyelid fusion and epithelial differentiation at the ocular surface during mouse embryonic development. Jpn J Ophthalmol. 2005;49(3):195-204.

3. Ezra DG, Beaconsfield M, Collin R. Floppy eyelid syndrome: stretching the limits. Surv Ophthalmol. 2010;55(1):35-46.

4. Kozel BA, Su CT, Danback JR, et al. Biomechanical properties of the skin in cutis laxa. J Invest Dermatol. 2014;134(11):2836-2838.

5. Liao CK, Tsai FC, Fong TH, Hu CM, Wei PL, Su CH. Damage from periorbital ageing to the multilayered structures and resilience of the skin in Chinese population. Int J Exp Pathol. 2013;94(3):188-194.

6. Ogawa R, Hsu CK. Mechanobiological dysregulation of the epidermis and dermis in skin disorders and in degeneration. $J$ Cell Mol Med. 2013;17:817-822.

7. Nagi KS, Carlson JA, Wladis EJ. Histologic assessment of dermatochalasis: elastolysis and lymphostasis are fundamental and interrelated findings. Ophthalmology. 2011;118(6):1205-1210.

8. Park JS, Ha SW, Lew H. Histopathologic properties of eyelid skin and conjunctiva in patients with dermatochalasis. J Korean Ophthalmol Soc. 2011;52(5):582-588.

9. Daxer A, Misof K, Grabner B, Ettl A, Fratzl P. Collagen fibrils in the human corneal stroma: structure and aging. Invest Ophthalmol Vis Sci. 1998;39(3):644-648.

10. Pawlaczyk M, Lelonkiewicz M, Wieczorowski M. Age-dependent biomechanical properties of the skin. Postepy Dermatol Alergol. 2013; 30(5):302-306.

11. Urban Z, Davis EC. Cutis laxa: intersection of elastic fiber biogenesis, TGFbeta signaling, the secretory pathway and metabolism. Matrix Biol. 2014;33:16-22.
12. Kara N, Bozkurt E, Baz O, et al. Corneal biomechanical properties and intraocular pressure measurement in Marfan patients. $J$ Cataract Refract Surg. 2012;38(2):309-314.

13. Muniesa M, March A, Sanchez-de-la-Torre M, Huerva V, Jurjo C, Barbe Illa F. Corneal biomechanical properties in floppy eyelid syndrome. Cornea. 2015;34(5):521-524.

14. Kaushik S, Pandav SS, Banger A, Aggarwal K, Gupta A. Relationship between corneal biomechanical properties, central corneal thickness, and intraocular pressure across the spectrum of glaucoma. $\mathrm{Am} \mathrm{J} \mathrm{Oph-}$ thalmol. 2012;153(5):840.e-849.e.

15. Piñero DP, Alcón N. In vivo characterization of corneal biomechanics. $J$ Cataract Refract Surg. 2014;40(6):870-887.

16. Vellara HR, Patel DV. Biomechanical properties of the keratoconic cornea: a review. Clin Exp Optom. 2015;98(1):31-38.

17. Jacobs LC, Liu F, Bleyen I, et al. Intrinsic and extrinsic risk factors for sagging eyelids. JAMA Dermatol. 2014;150(8):836-843.

18. Kotecha A, Russell RA, Sinapis A, Pourjavan S, Sinapis D, Garway-Heath DF. Biomechanical parameters of the cornea measured with the ocular response analyzer in normal eyes. BMCOphthalmol.2014; $14: 11$.

19. Luce DA. Determining in vivo biomechanical properties of the cornea with an ocular response analyzer. J Cataract Refract Surg. 2005;31(1): $156-162$.

20. Touboul D, Roberts C, Kérautret J, et al. Correlations between corneal hysteresis, intraocular pressure, and corneal central pachymetry. $J$ Cataract Refract Surg. 2008;34(4):616-622.

21. Shah S, Laiquzzaman M, Cunliffe I, Mantry S. The use of the Reichert ocular response analyser to establish the relationship between ocular hysteresis, corneal resistance factor and central corneal thickness in normal eyes. Cont Lens Anterior Eye. 2006;29(5):257-262.

22. Simsek IB, Yilmaz B, Yildiz S, Artunay O. Effect of upper eyelid blepharoplasty on vision and corneal tomographic changes measured by pentacam. Orbit. 2015;34(5):263-267.

23. Zinkernagel MS, Ebneter A, Ammann-Rauch D. Effect of upper eyelid surgery on corneal topography. Arch Ophthalmol. 2007;125(12): $1610-1612$.

24. Kim JW, Lee H, Chang M, Park M, Lee TS, Baek S. What causes increased contrast sensitivity and improved functional visual acuity after upper eyelid blepharoplasty? J Craniofac Surg. 2013;24(5): $1582-1585$.

25. Rogers SA, Khan-Lim D, Manners RM. Does upper lid blepharoplasty improve contrast sensitivity? Ophthal Plast Reconstr Surg. 2012; 28(3):163-165.

26. Svedbergh B. Effects of artificial intraocular pressure elevation on the corneal endothelium in the vervet monkey (Cercopithecus ethiops). Acta Ophthalmol (Copenh). 1975;53(6):839-855.

27. Setala K. Response of human corneal endothelial cells to increased intraocular pressure. Acta Ophthalmol Suppl. 1980;144:1-38.

28. Ezra DG, Beaconsfield M, Sira M, Bunce C, Wormald R, Collin R. The associations of floppy eyelid syndrome: a case control study. Ophthalmology. 2010;117(4):831-838.

29. Gu W, Liu W, Yang X, et al. Cutis laxa: analysis of metalloproteinases and extracellular matrix expression by immunohistochemistry and histochemistry. Eur J Dermatol. 2011;21(5):717-721.

30. Schlötzer-Schrehardt U, Stojkovic M, Hofmann-Rummelt C, Cursiefen C, Kruse FE, Holbach LM. The pathogenesis of floppy eyelid syndrome: involvement of matrix metalloproteinases in elastic fiber degradation. Ophthalmology. 2005;112(4):694-704.

31. Shetty R, Ghosh A, Lim RR, et al. Elevated expression of matrix metalloproteinase-9 and inflammatory cytokines in keratoconus patients is inhibited by cyclosporine A. Invest Ophthalmol Vis Sci. 2015;56(2): 738-750.

32. Sun MT, Pham DT, O'Connor AJ, et al. The biomechanics of eyelid tarsus tissue. J Biomech. 2015;48(12):3455-3459.

33. Kymionis GD, Grentzelos MA, Liakopoulos DA, Kontadakis GA, Stojanovic N. Corneal collagen crosslinking failure in a patient with floppy eyelid syndrome. J Cataract Refract Surg. 2014;40(9): $1558-1560$. 
34. Donnenfeld ED, Perry HD, Gibralter RP, Ingraham HJ, Udell IJ. Keratoconus associated with floppy eyelid syndrome. Ophthalmology. 1991;98(11):1674-1678.
35. Hatami-Marbini H, Rahimi A. Stiffening effects of riboflavin/UVA corneal collagen cross-linking is hydration dependent. $J$ Biomech. 2015;48(6):1052-1057.

\section{Publish your work in this journal}

Clinical Interventions in Aging is an international, peer-reviewed journal focusing on evidence-based reports on the value or lack thereof of treatments intended to prevent or delay the onset of maladaptive correlates of aging in human beings. This journal is indexed on PubMed Central, MedLine,
CAS, Scopus and the Elsevier Bibliographic databases. The manuscript management system is completely online and includes a very quick and fair peer-review system, which is all easy to use. Visit http://www.dovepress. $\mathrm{com} /$ testimonials.php to read real quotes from published authors. 